\title{
Analisis Kandungan Acid Detergen Fiber (ADF) dan Neutral Detergen Fiber (NDF) Pakan Kombinasi Serbuk Gergaji Kayu Jati (Tectona grandits L.f) dan Murbei (Morusalba) yang Difermentasi dengan Penambahan Trichoderma sp. sebagai Pakan Ternak Ruminansia
}

\author{
Analysis of Acid Detergen Fiber (ADF) and Neutral Detergen Fiber (NDF) Content \\ of Feed Combination of Teak Sawdust (Tectona grandits L.f) and Mulberry (Morus alba) \\ Fermented by Addition of Trichoderma sp. as Ruminant Animal Feed \\ Bahrum Nur*, Munir, Muh. Jurhadi Kadir \\ Program Studi Peternakan, Fakultas Pertanian, Peternakan dan Perikanan, Universitas \\ Muhammadiyah Parepare, 91132, Sulawesi Selatan, Indonesia \\ *Korespondensi Email: Bahrumnur@gmail.com
}

\begin{abstract}
ABSTRAK
Penelitian ini bertujuan untuk mengetahui pengaruh kandungan Acid Detergen Fiber ADF dan Neutral Detergen Fiber NDF pakan fermentasi berbahan dasar serbuk gergaji kayu jati (Tectona grandits L.f) dengan penambahan murbei (Morus alba) yang difermentasi dengan penambahan Trichoderma sp. Empat perlakuan dan tiga ulangan. S1: serbuk gergaji kayu jati $40 \%$, murbei $20 \%$ dan bahan pakan lain $40 \%$ (dedak 30\%, tepung ikan $8 \%$, mineral mix 1\%, garam 1\%). S2: serbuk gergaji kayu jati 30\%, murbei 30\% dan bahan pakan lain 40\%. S3: serbuk gergaji kayu jati $20 \%$, murbei $40 \%$ dan bahan pakan lain $40 \%$. S3: serbuk gergaji kayu jati $20 \%$, murbei $40 \%$ dan bahan pakan lain $40 \%$. S4: serbuk gergaji kayu jati $10 \%$, murbei $50 \%$ dan bahan pakan lain $40 \%$. Hasil Penelitian menunjukkan bahwa kandungan $\mathrm{ADF}$ rata-rata adalah $\mathrm{S} 1=35,5 \%, \mathrm{~S} 2=30,76 \%$, S3 $=28 \%$, S4 $=21,48 \%$ dan NDF yaitu S1 = 44,15\%, S2 = 41,6\%, S3 = 31,65\%, S4 = 33,2\%.Kandungan ADF dan NDF terus menurun seiring dengan penambahan murbei (Morus alba) danpengurangan serbuk gergaji kayu jati (Tectona grandits L.f). Analisis data menunjukkan perbedaan yang nyata $(\mathrm{P}<0,05)$ terhadap kandungan ADF.Pada NDF juga menunjukkan perbedaan yang nyata $(P<0,05)$.
\end{abstract}

Kata kunci: Serbuk Gergaji Kayu Jati (Tectona grandits L.f), Murbei (Morus alba), Trichoderma sp., Pakan Fermentasi, Kandungan ADF dan NDF

\begin{abstract}
The purpose of this study is how to influence the Acid Detergen Fiber (ADF) and Neutral Detergen Fiber (NDF) content of fermented feed made from teak sawdust (Tectona grandits L.f) with the addition of mulberry (Morus alba) fermented by adding Trichoderma sp. Four treatments and three replications. S1: $40 \%$ teak sawdust, $20 \%$ mulberry and $40 \%$ other feed ingredients $(30 \%$ bran, $8 \%$ fish meal, $1 \%$ mineral mix, $1 \%$ salt). S2: Teak sawdust $30 \%$, mulberry $30 \%$ and other feed ingredients 40\%. S3: 20\% teak sawdust, $40 \%$ mulberry and $40 \%$ other feed ingredients. S3: $20 \%$ teak sawdust, $40 \%$ mulberry and $40 \%$ other feed ingredients. S4: teak sawdust $10 \%$, mulberry $50 \%$ and other feed ingredients $40 \%$. The results showed that the average ADF content was $\mathrm{S} 1=35.5 \%$, $\mathrm{S} 2=30.76 \%$,


$\mathrm{S} 3=28 \%, \mathrm{~S} 4=21.48 \%$ and NDF namely S1 $=44.15 \%, \mathrm{~S} 2=41.6 \%, \mathrm{~S} 3=31.65 \%, \mathrm{~S} 4$ $=33.2 \%$. The content of ADF and NDF continues to decrease along with the addition of mulberry (Morus alba) and reduction of teak sawdust (Tectona grandits Lf). Data analysis showed a significant difference $(\mathrm{P}<0.05)$ to the ADF content. The NDF also showed a significant difference $(\mathrm{P}<0.05)$.

Keywords: Teak Sawdust (Tectona grandits L.f), Mulberry (Morus alba), Trichoderma sp., Fermented feed, ADF and NDF content

\section{PENDAHULUAN}

Pakan adalah semua yang bisa dimakan oleh ternak dan tidak mengganggu kesehatannya. Pada umumnya pengertian pakan (feed) digunakan untuk hewan yang meliputi kuantitatif, kualitatif, kontinuitas serta keseimbangan zat pakan yang terkandung di dalamnya. Sedangkan bahan pakan adalah (bahan makanan ternak) adalah segalah sesuatu yang dapat diberikan kepada ternak baik yang berupa bahan organik maupun anorganik. Bahan organik yang terkandung dalam bahan pakan,berupa protein, lemak, serat kasar, bahan ekstrak tanpa nitrogen, sedangkan bahan anorganik seperti calsium, phospor, magnesium, kalium, natrium.Pakan berfungsi untuk memenuhi kebutuhan ternak baik untuk hidup pokok, pertumbuhan, reproduksi dan produksi. Tiga faktor penting dalam kaitan penyedian hijauan bagi ternak ruminansia adalah ketersedian pakan harus dalam jumlah yang cukup, mengandung nutrien yang baik, dan berkesinambungan sepanjang tahun. Ketersedian hijauan umumnya berfluktuasi mengikuti pola musim, dimana produksi hijauan melimpah di musim hujan dan sebaliknya terbatas dimusim kemarau upaya pencarian baham pakan perlu dilakukan dan salah satu bahan pakan yang potensial dapat digunakan adalah limbah pengrajin kayu yaitu serbuk gergaji.

Ketersediaan serbuk gergaji kayu cukup banyak, khususnya pada sentra kerajinan tangan. Serbuk gergaji kayu merupakan limbah dari hasil penggergajian kayu dan umumnya banyak digunakan sebagai bahan pembakar batu bata. Namun, akan lebih ekonomis kalau serbuk gergaji kayu tersebut dapat dimanfaatkan sebagai bahan pakan limbah berserat.Jenis serbuk gergaji yang digunakan pada penelitian ini adalah serbuk gergaji kayu jati (Tectona grandits L.f). Adapun kendala utama dari pemanfaatan serbuk gergaji sebagai salah satu bahan pakan ternak yaitu kandungan serat kasar tinggi dan protein serta kecernaan yang rendah. Penggunaan serbuk gergaji secara langsung sebagai pakan tunggal tidak dapat memenuhi pasokan nutrisi yang dibutuhkan ternak. Untuk dapat memanfaatkan limbah yang berlimpah maka perlu dilakukan suatu upaya peningkatan 
daya guna dari limbah tersebut melalui suatu teknologi pakan yang tepat guna. Salah satu teknologi pakan tepat guna yang dilakukan dalam pengolahan bahan pakan ternak adalah bioteknologi melalui fermentasi. Fermentasi limbah dalam bentuk serbuk gergaji belum digunakan secara optimal, kebanyakan hanya untuk bahan bakar boiler atau dibakar tanpa pemanfaatan yang berarti dan banyak menimbulkan masalah terhadap lingkungan (Febrianto,1999).

Untuk mengatasi minimnya kandungan nutrisi pada serbuk gergaji maka perlu kombinasi bahan pakan lain yaitu tanaman murbei. Tanaman murbei mempunyai potensi sebagai bahan pakan yang berkualitas karena potensi produksi, kandungan nutrisi dan daya adaptasi tumbuhnya yang baik (Singh and Makkar, 2002). Produksi daun murbei sangat bervariasi, tergantung pada varietas, lahan, ketersediaan air dan pemupukan. Martin et al (2002) melaporkan produksi biomassa murbei mencapai 25 ton BK/ha/tahun dan produksi daun sebesar 16 ton BK/ha/tahun, sedangkan Boschini (2002) melaporkan produksi daun sebesar 19 ton $\mathrm{BK} / \mathrm{ha} /$ tahun.

Bahan pakan yang memiliki kandungan nutrisi yang tinggi, salah satunya yaitu daun murbei dimana daun murbei mengandung protein 15,71 - 22,59 \%, lemak 3,70-6,15\%, dan serat kasar 8-16,8\%. Hijauan murbei mempunyai nilai nutrisi yang tinggi dari segi kandungan protein dan kecernaan sehingga dapat digunakan sebagai suplemen dalam pakan sapi perah. Sebagai suplemen biomassa murbei (batang, ranting dan daun) dapat digunakan sebagai pengganti ransum konsentrat sampai $75 \%$ tanpa mempengaruhi produksi dan kualitas susu (Purbowati ,2009).

Daun murbei memiliki senyawa aktif yang mampu menghambat hidrolisis oligosakarida menjadi monomer-monomernya. Keberadaan daun murbei yang mengandung senyawa aktif dalam ransum dapat menyediakan karbohidrat nonstruktural secara seimbang dan berkesinambungan dalam sistem rumen, sehingga fermentabilitas pakan berserat tinggi menjadi lebih baik (Syahrir dkk., 2009).

Tujuan pembuatan pakan fermentasi adalah untuk meningkatkan nutrisi pakan dan mengawetkan hijauan atau bijian yang berlimpah untuk digunakan pada saat kesulitan untuk mendapatkan hijauan. Trichoderma sp. pada pengolahan bahan pakan yang akan dilakukan adalah dengan proses fermentasi, yang memanfaatkan kapang penghasil enzim, sehingga diharapkan dengan bantuan enzim yang dihasilkan oleh Trichoderma sp. dapat mendegradasi dan meningkatkan kandungan nutrisi (Volk, 2004). 
Melalui penelitian ini diharapkan salah satu formulasi pakan fermentasi berbahan dasar serbuk gergaji kayu jati (Tectona grandits L.f) dengan kombinasi tanaman murbei (Morus alba) dengan penambahan Trichoderma sp dapat direkomendasikan sebagai pakan ternak ruminansia yang memiliki kualitas pakan yang baik sehingga produktivitas ternak ruminansia dapat meningkat pesat.

\section{METODE}

Penelitian ini menggunakan Rancangan Acak lengkap (RAL) dengan 4 perlakuan dan 3 ulangan (Gaspersz, 1991). Adapun susunan ransum yang digunakan selama penelitian sebagai berikut disajikan pada Tabel 1.

Tabel 1. Susunan Formulasi Ransum

\begin{tabular}{clcccc}
\hline \multirow{2}{*}{ NO } & \multicolumn{2}{c}{ Bahan Pakan } & \multicolumn{4}{c}{ Perlakuan (\%) } \\
\cline { 2 - 5 } & & S1 & S2 & S3 & S4 \\
\hline 1 & $\begin{array}{l}\text { Serbuk gergaji kayu jati } \\
\text { (Tectona grandits L.f) }\end{array}$ & 40 & 30 & 20 & 10 \\
2 & Murbei (Morus alba) & 20 & 30 & 40 & 50 \\
3 & Dedak & 30 & 30 & 30 & 30 \\
4 & Tepung Ikan & 8 & 8 & 8 & 8 \\
5 & Mineral Mix & 1 & 1 & 1 & 1 \\
6 & Garam & 1 & 1 & 1 & 1 \\
& Jumlah & 100 & 100 & 100 & 100 \\
\hline
\end{tabular}

\section{Pelaksanaan Penelitian}

Serbuk Gergaji kayu jati (Tectona Grandits L.f) yang berasal dari Kecamatan bacukiki kota Parepare ditambahkan murbei (Morus alba), tepung ikan, mineral mix dan garam (sesuai jumlah bahan pakan pada Tabel 2. susunan formulasi ransum) kemudian disemprot dengan air yang telah dicampur molases dan Trichoderma sp. 5\% sampai kelembaban 55-60\% dicampur hingga merata (kecuali kontrol), dimasukkan kedalam kantong plastik kemudian di inkubasi selama 2 minggu.

\section{Parameter yang Diukur}

Parameter yang diukur dalam penelitian ini adalah kandungan NDF dan ADF pakan kombinasi serbuk gergaji (Tectona Grandits L.f)dan biomassa murbei(Morus alba) yang di 
fermentasi dengan penambahan Trichoderma sp penelitian ini dilakukan untuk mengetahui NDF dan ADF dengan menggunakan analisis Van Soest ( Tillman dkk., 1989).

Analisis kandungan NDF meliputi:

a. Timbang sampel 0,2 gram (a gram)

b. Masukkan kedalam tabung reaksi $50 \mathrm{~mL}$

c. Tambahkan $25 \mathrm{~mL}$ larutan NDS, kemudian tutup rapat tabung reaksi tersebut

d. Refluks dalam air mendidih selama 1 jam

e. Saring dengan sintered glass yang telah diketahui beratnya (b gram) sambil diisap dengan pompa vacum

f. Cuci dengan lebih kurang $100 \mathrm{ml}$ airmendidih hinggah busa hilang

g. Ovenkan pada suhu $100^{\circ} \mathrm{C}$ selama 8 jam atau dibiarkan bermalam

h. Dinginkan dalam eksikator lebih kurang $1 / 2$ jam kemudian timbang (c gram ).

\section{Analisis Kandungan ADF}

a. Timbang sampel 0,3 gram (a gram ) kemudian masukkan kedalam tabung reaksi 50 $\mathrm{mL}$

b. Tambahkan $40 \mathrm{~mL}$ larurtan ADF kemudian tutup rapat tabung reaksi tersebut

c. Refluks dalam air mendidih selama 1 jam

d. Saring dengan sintered glass yang telah diketahui beratnya ( b gram ) sambil diisap degan pompa vacum.

e. Cuci dengan air mendidih kurang lebih $100 \mathrm{ml}$ sampai busa hilang dan $50 \mathrm{~mL}$ alcohol

f. Ovenkan pada suhu $100^{\circ} \mathrm{C}$ selama 8 jam atau dibiarkan bermalam

g. Dinginkan dalam eksikator lebih kurang 1/2 jam kemudian timbang (c gram ).

\section{Analisis Data}

Data yang diperoleh dari analisis laboratorium diolah secara statistik menggunakan Rancangan Acak Lengkap (RAL) dianalisis menggunakan bantuan SPSS versi 16 (Gaspersz, 1991 


\section{HASIL DAN PEMBAHASAN}

\section{Kandungan ADF (Acid Detergent Fiber)}

Berdasarkan penelitian yang telah dilaksanakan diperoleh hasil kandungan ADF pakan kombinasi serbuk gergaji kayu jati (Tectona grandits L.f ) dan murbei (Morus alba) yang difermentasi dengan penambahan Trichoderma sp., disajikan pada Tabel 2.

Tabel 2. Rata-Rata Kandungan ADF pada Masing-Masing Perlakuan (\%)

\begin{tabular}{ccccc}
\hline \multirow{2}{*}{ Parameter } & \multicolumn{5}{c}{ Perlakuan } \\
\cline { 2 - 5 } & $\mathrm{S} 1$ & $\mathrm{~S} 2$ & $\mathrm{~S} 3$ & $\mathrm{~S} 4$ \\
\hline $\mathrm{ADF}(\%)$ & $35,5^{\mathrm{a}}$ & $30,76^{\mathrm{b}}$ & $28^{\mathrm{c}}$ & $21,48^{\mathrm{d}}$ \\
\hline
\end{tabular}

Keterangan: Superskrip yang berbedapadadiagram,menunjukkan perbedaan yang nyata $(\mathrm{P}<0,05)$ pada setiap perlakuan

Berdasarkan hasil sidik ragam menunjukkan bahwa perlakuan S1 pada perlakuan S2,S3 dan S4 fermentasi berpengaruh sangat nyata $(\mathrm{P}<0,05)$ terhadap kandungan ADF formulasi pakan kombinasi serbuk gergaji kayu jati (Tectona grandits L.f) dan murbei (Morus alba) yang difermentasi.

Kandungan ADF formulasi pakan kombinasi serbuk gergaji kayu jati (Tectona grandits L.f)dan murbei (Morus alba) yang difermentasi Trichoderma sp, menunjukkan bahwa S1 (35,5\%) berpengaruh sangat nyata, dimana S2 (30,76\%), S3 (28\%) dan S4 (21,48\%) selama perlakuan menunjukkan penurunan kandungan NDF pada perlakuan S4. NDF mewakili kandungan dinding sel yang terdiri dari lignin, selulosa, hemiselulosa dan protein yang berikatan dengan dinding sel.

Kandungan Acid Detergen Fiber (ADF) formulasi pakan kombinasi serbuk gergaji kayu jati (Tectona grandits L.f) dan murbei (Morus alba) yang difermentasi dengan penambahan Trichoderma sp. Pada perlakuan S1 menghasilkan kandungan tertinggi yaitu (35,5\%) dan S4 menghasilkan kandungan terendah yaitu (21,48\%). Pakan kombinasi serbuk gergaji kayu jati (Tectona grandits L.f) dan murbei (Morus alba) yang difermentasi dengan penambahan Trichoderma sp, berpengaruh sangat nyata pada kandungan ADF S1, S2, S3 dan S4.

Data rata-rata kandungan ADF formulasi Pakan kombinasi serbuk gergaji kayu jati (Tectona grandits L.f) dan murbei (Morus alba) yang difermentasi dengan penambahan Trichoderma sp dapat dilihat pada Gambar 1. 
Bahrum Nur dkk., 61

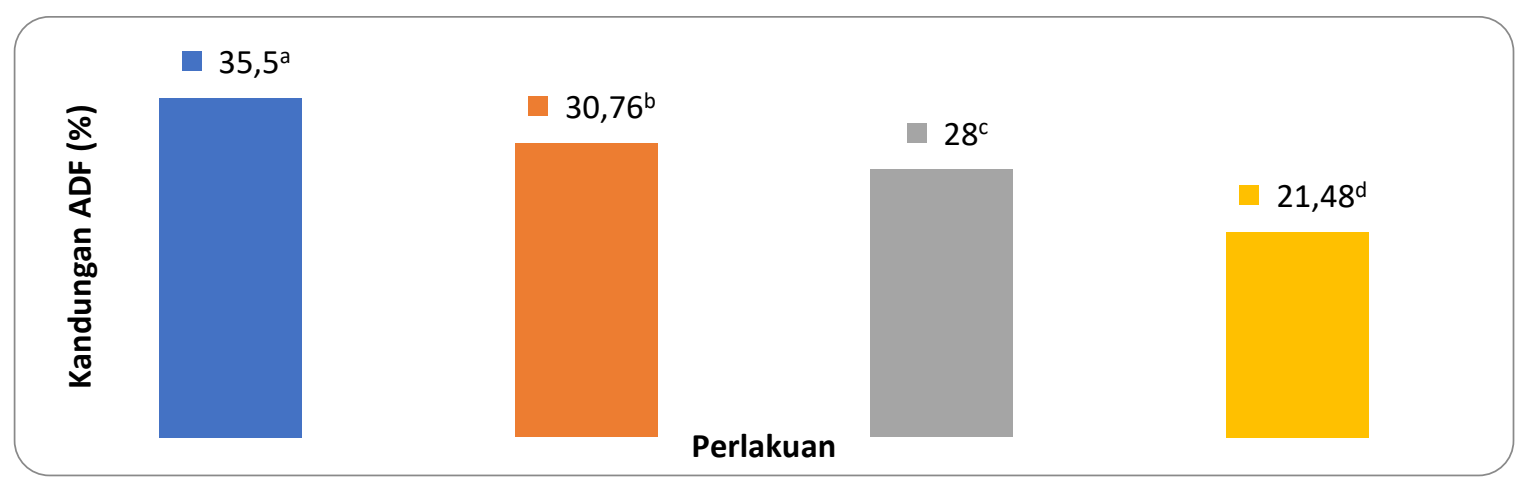

Gambar 1. Rataan ADF Pakan Kombinasi Serbuk Gergaji (Tectona Grandits L.F) dan Murbei (Morus Alba) yang Difermentasi dengan Penambahan Trichoderma Sp.

Kandungan ADF pada penelitian diperoleh berkisar antara 21,48\% sampai 35,5\%. Perlakuan dengan penambahan serbuk gergaji kayu jati (Tectona grandits L.f) dan murbei (Morus alba) yang difermentasi dengan penambahan Trichoderma sp. Menunjukkan perbedaanyang nyata terhadap kandungan ADF. Hal ini sesuai dengan pendapat Arif (2001) yang menyatakan bahwa telah terjadi perenggaangan ikatan lignoselulosa dan ikatan hemiselulosa yang menyebabkan isi sel (NDS) akan meningkat.

Hasil penelitian menunjukkan kecenderungan terjadi penurunan kandungan ADF seiring dengan penambahan murbei (Morus alba)dan pengurangan serbuk gergaji kayu jati (Tectona grandits L.f). Semakin banyak penambahan murbei (Morus alba) dan sedikit serbuk gergaji kayu jati (Tectona grandits L.f)maka kandungan ADF menurun. Kandungan ADF yang semakin turun maka tingkat kecernaan akan pakan semakin meningkat dan menunjukkan kualitas pakan semakin membaik. Hal ini mengindikasikan bahwa murbei menunjang penurunan kandungan ADF..

Analisis ADF digunakan sebagai suatu langkah persiapan untuk mendeterminasi lignin, sehingga hemiselulosa dapat diestimasi dari perbedaan kandungan ADF. ADF dapat digunakan untuk mengestimasi kecernaan bahan kering dan energi makanan ternak. Kandungan ADF menurun yaitu pada perlakuan S1,S2,S3. Hal ini sesuai dengan pendapat Arief (2001) yang menyatakan bahwa menurunnya NDF dan ADF disebabkan karena selama berlangsungnya fermentasi terjadi perenggangan ikatan lignoselulosa dan ikatan hemiselulosa yang menyebabkan isi sel yang terikat akan larut dalam larutan neutral 
detergent. Hal ini menyebabkan isi sel (NDS) akan meningkat, sedangkan komponen pakan yang tidak larut dalam larutan detergent (NDF) mengalami penurunan

\section{Kandungan NDF (Neutral Detergent Fiber)}

Berdasarkan penelitian yang telah dilaksanakan diperoleh hasil kandungan NDF pakan kombinasi serbuk gergaji kayu jati (Tectona grandits L.f) dan murbei (Morus alba) yang difermentasi dengan penambahan Trichoderma sp., dapat dilihat pada Tabel 2 berikut:.

Tabel 2. Rata-Rata Kandungan NDF pada Masing Masing Perlakuan (\%)

\begin{tabular}{lllll}
\hline \multirow{2}{*}{ Parameter } & \multicolumn{4}{c}{ Perlakuan \% } \\
\cline { 2 - 5 } & S1 & S2 & S3 & S4 \\
\hline NDF(\%) & $44,15^{\mathrm{d}}$ & $41,6^{\mathrm{c}}$ & $31,65^{\mathrm{a}}$ & $33,2^{\mathrm{b}}$ \\
\hline
\end{tabular}

Keterangan : Superskrip yang berbeda padadiagram,menunjukkan perbedaan yang nyata $(\mathrm{P}<0,05)$ pada setiap perlakuan.

Berdasarkan hasil sidik ragam menunjukkan bahwa perlakuan S1 pada perlakuan S2, S3 dan S4 fermentasi berpengaruh sangat nyata $(P<0,05)$ terhadap kandungan NDFformulasi pakan kombinasi serbuk gergaji kayu jati (Tectona grandits L.f) dan murbei (Morus alba) yang difermentasi.

Kandungan NDF formulasi pakan kombinasi serbuk gergaji kayu jati (Tectona grandits L.f) dan murbei (Morus alba) yang difermentasi dengan Trichoderma sp, menunjukkan bahwa S1 (44,15\%) berpengaruh sangat nyata , dimana S2 (41,6\%), S3 (31,65\%) dan S4 (33,2\%) selama perlakuan menunjukkan penurunan kandungan NDF pada perlakuan S3.NDF mewakili kandungan dinding sel yang terdiri dari lignin, selulosa, hemiselulosa dan protein yang berikatan dengan dinding sel.

Kandungan neutral detergent fiber (NDF) formulasi pakan kombinasi serbuk gergaji kayu jati (Tectona grandits L.f) dan murbei (Morus alba) yang difermentasi dengan penambahan Trichoderma sp. Pada perlakuan S1 menghasilkan kandungan tertinggi yaitu $(44,15 \%)$ dan S3 menghasilkan kandungan terendah yaitu (31,65\%). Pakan kombinasi serbuk gergaji kayu jati (Tectona grandits L.f) dan murbei (Morus alba) yang difermentasi dengan penambahan Trichoderma sp, berpengaruh sangat nyata pada kandungan NDF S1, S2 dan S3.

Data rata rata kandungan NDF formulasi Pakan kombinasi serbuk gergaji kayu jati (Tectona grandits L.f) dan murbei (Morus alba) yang difermentasi dengan penambahan Trichoderma sp.dapat dilihat pada Gambar 2. 


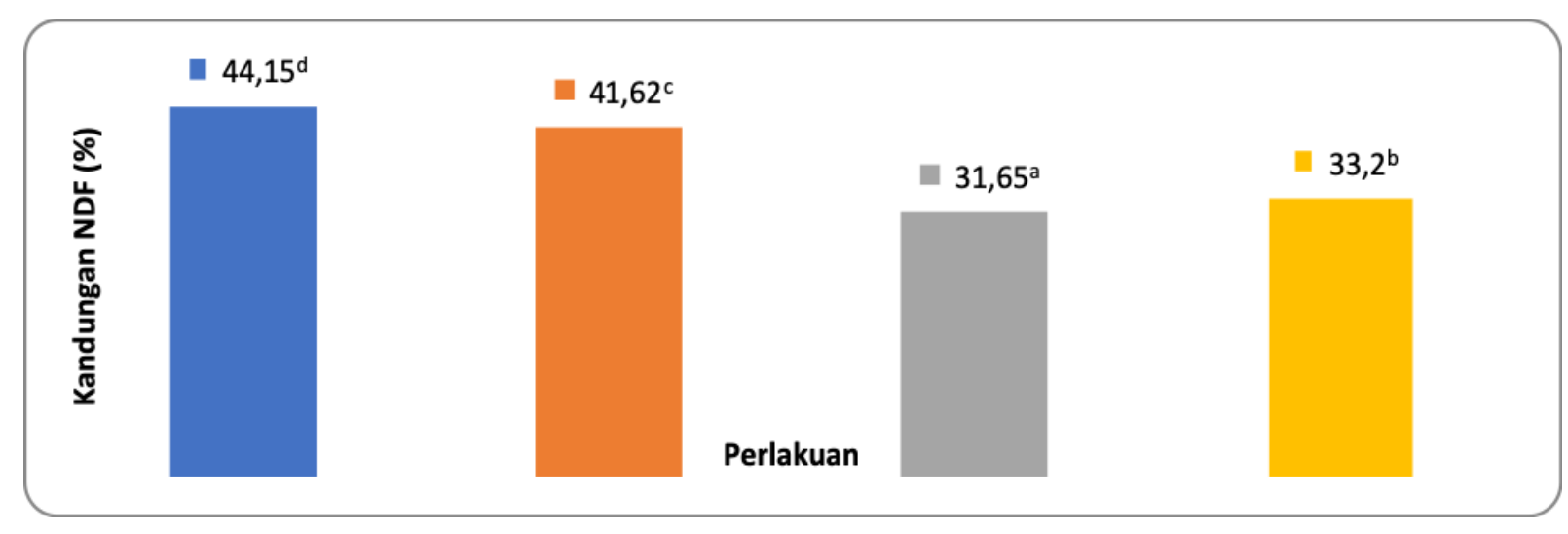

Gambar 2. Rataan NDF Pakan Kombinasi Serbuk Gergaji (Tectona Grandits L.f) dan Murbei (Morus Alba) yang Difermentasi dengan Penambahan Trichoderma sp.

Kandungan NDF pada penelitian diperoleh berkisar antara 31,65\% sampai 44,15\%. Perlakuan dengan penambahan serbuk gergaji kayu jati (Tectona grandits L.f) dan murbei (Morus alba) yang difermentasi dengan penambahan Trichoderma sp. Perbedaan yang nyata dan mengalami penurunan pada tiap perlakuaan. Hal ini sesuai dengan pendapat Akmal (2003) yang menyatakan bahwa penurunan kandungan NDF disebabkan karena selama berlangsungnya fermentasi terjadi pemutusan ikatan lignoselulosa dan aktifitas mikroba yang berkembang.

Berdasarkan Hasil analisis van soest diketahui bahwa S3 merupakan perlakuan yang terbaik karena kandungan NDF menurun.hal menunjukkan bahwa proses fermentasi berlangsung baik pada perlakuan tersebut, dan pada perlakuan S4 menunjukkan terjadi peningkatan kandungan NDF seiring dengan penambahan murbei (Morus alba)dan pengurangan serbuk gergaji kayu jati (Tectona grandits L.f) hal ini menyebabkan proses fermentasi tidak optimal lagi. Peningkatan kandungan NDF pada perlakuan S4 disebabkan karena kandungan dari enzim selulosa yang terdapat dalam Trichoderma sp terlebih dahulu akan akan mendegradasi komponen isi sel yang mudah larut seperti protein kasar, lemak kasar, serta karbohidrat sehingga persentase komponen serat kasar akan meningkat. Kandungan NDF meningkat maka tingkat kecernaan ternak rendah begitupun sebaliknya, kandungan NDF semakin turun, maka tingkat kecernaan akan pakan semakin meningkat dan menunjukkan bahwa kualitas pakan semakin membaik.

Penurunan kadar NDF akan mempengaruhi kadar serat kasaryang menunjukkan enzim lignoselulosa yang dihasilkan oleh murbei mampu melonggarkan lignin dan hemiselulosa sehingga ikatan yang tadi kuat menjadi terurai. Hal ini sesuai dengan 
pendapat Suparjo (2008) yang menyatakan bahwa NDF mewakili kandungan dinding sel yang terdiri dari lignin, selulosa, hemiselulosa, dan protein yang berikatan dengan dinding sel. Bagian yang tidak terdapat sebagai residu dikenal sebagai Detergent Soluble (NDS) yang mewakili isi sel dan mengandung lipid, gula, asam organik, non protein nitrogen, peptin, protein terlarut dan bahan terlarut dalam air. Serat kasar terutama mengandung selulosa dan hanya sebagian lignin, sehingga nilai ADF lebih kurang 30 persen lebih tinggi dari serat kasar pada bahan yang sama.

Penurunan kadar NDF disebabkan karena meningkatnya lignin pada tanaman mengakibatkan menurunnya hemiselulosa.Hal ini sesuai dengan pendapat Crampton and Haris (1996) yang menyatakan bahwa meningkatnya lignin pada tanaman mengakibatkan menurunnya hemiselulosa. Hemiselulosa merupakankomponen dinding sel yang dapat dicerna oleh mikroba. Tingginya kadar lignin menyebabkan mikroba tidak mampu menguasai hemiselulosa dan selulosa secara sempurna. kandungan dari enzim selulase yang terdapat pada Trichoderma akan melonggarkan ikatan ligno-selulosa dan lignohemiselulosa.

\section{KESIMPULAN}

Berdasarkan hasil dan pembahasan dapat disimpulkan bahwa dengan penambahan murbei (Morus alba) dapat menurunkan kandungan ADF dan NDF pakan kombinasi serbuk gergaji kayu jati (Tectona grandits L.f) dan murbei (Morus alba) yang difermentasi dengan Trichoderma sp. Sebagai pakan ternak ruminansia dengan hasil yang terbaik yaitu pada perlakuan S3 dengan hasil 31,65\%.

Perlu dilakukan penelitian lanjutan untuk mengetahui dampak dari pemberian pakan kombinasi serbuk gergaji kayu jati (Tectona grandits L.f) dan murbei (Morusalba) dengan level yang berbeda terhadap pertambahan berat badan, konsumsi, konversi pakan dan karakteristik cairan rumen ternak ruminansia.

\section{DAFTAR PUSTAKA}

Arief, R. 2001. Pengaruh penggunaan jerami pada amoniasi terhadap daya cerna NDF, ADF dan ADS dalam ransum domba lokal. Jurnal Agroland, 8(2), 208-215.

Boschini, C. F. 2002. Nutritional quality of mulberry cultivation for ruminant feeding.In:Mulberry for Animal Production., Ed. M. D. Sánchez. Procciding. of an electronic conference. Carried out in May and August 2000. Rome: FAO Animal Production and Health, pp. 173-182. 
Bahrum Nur dkk., 65 JiiP Volume 5 Nomor 2: 55-65, Desember 2019

Crampton, E.W., and Haris, L.E. 1996. Applied Animal Nutrision 1st Ed. The Engsminger Publishing Company. California, U.S. A.

Febrianto. 1999. pirolisis serbuk gergaji secara batch. Laporan Penelitian Proses Kimia. Jurusan Teknik Kimia. Universitas Gadjah Mada, Yogyakarta.

Gaspersz, V. 1991. Metode Perancangan Percobaan. CV. Armico, Bandung.

Purbowati, E. 2009. Usaha Penggemukan Domba. Penebar Swadaya, Jakarta.

Syahrir, S., Wiryawan, K.G., Parakkasi, A., Winugroho, M., dan Sari, O.N.P. 2009. Efektivitas daun murbei sebagai pengganti konsentrat dalam sistemrumen in vitro. Media Peternakan, 32 (2).

Singh, B., H P S and Makkar,. 2002. The potential of mulberry foliage as a feed supplement in India. Di dalam : Sánchez MD. Editor.Mulberry for animal production. Proceedings of an electronic conference. Carried out, May and August 2000. FAO Animal Production and Health, pp 139-156.

Suparjo. 2008. Degradasi Komponen Lignoselulosa oleh Kapang Pelapuk Putih. https://jajo66.files.wordpress.com/2008/10/ degradasi-lignoselulosa.pdf (22 Desember 2018).

Tillman, A.D., Hartadi, H., Reksohadiprodjo, S., Prawirokusumo, S., dan Lebdosoekojo, S. 1989. Ilmu Makanan Ternak Dasar. Gadjah Mada University Press, Yogyakarta.

Volk, T.J., 2004. Trichoderma viridae, the darkgreen parasitic mold and maker of fungaldigestedjeans. http :// botit. botany.wisc.edu/toms_fungi/ nov2004.html. (22 Desember 2018) 